\title{
24 \\ CONFIDENTIAL DRAFT AND STATEMENT OF 22 MAY 2000
}

\section{George Speight}

\section{Excellency:}

I am writing on behalf of the group of indigenous Fijians who took over the Parliament of Fiji on Friday 19 May 2000. The illegal and unconstitutional action that was taken is acknowledged. It represented a year's efforts on the part of a wide spectrum of the indigenous community to bring to the attention of the Government, our increasing concern in the way the People's Coalition government began to address issues that are of fundamental importance to the indigenous community of Fiji.

For example, the nature of the tenancy of indigenous-owned land to Indo-Fijian cane farmers, the progressive removal of affirmative action for the indigenous community which has lagged behind in every sector of the Fiji economy - in education, in commerce, in the professions, in management, in technical staff, etc.

The 1997 Constitution was rejected by eight of the fourteen Fijian provinces, however by a combination of parliamentary and not-soparliamentary manoeuvring, the Great Council of Chiefs approved the amended Constitution. In fact, the 1997 Constitution is not an amendment of the 1990 Constitution but represents a brand new Constitution.

To compound this serious error in judgement on the part of the indigenous political leadership, the SVT government with lack of foresight and prudence, at the tail end of its administration, introduced 
a completely new electoral legislation. Worse still, it did not give itself sufficient time, nor made any effort to understand the complications to the new electoral law.

There was also at this point of time, a growing discontent on the part of segments of the indigenous community. There was a 'ganging up' of at least two indigenous parties in its allocation of their preferences which ultimately led to the defeat not only of the SVT-led political party but also of the National Federation Party (NFP) which had been the premier party, overseeing the interests of the Indo-Fijian community over the last 30 years.

The People's Coalition Party was the major beneficiary of the Constitution and the new electoral legislation. Of the 71 seats in Parliament the Fiji Labour Party won 35 seats. With the support of other parties it was able to control some 61 seats in Parliament. The government that was subsequently formed comprises the Fiji Labour Party, the Fijian Association and two other smaller parties.

One of the basic concerns of the indigenous people when the draft of the Constitution was being discussed was the likely loss of indigenous political leadership and control. The indigenous people remain distrustful of the Indo-Fijian political intentions. The subsequent events following the formation of the People's Coalition government in May 1999 confirmed and convinced indigenous body politic that their fears and trepidation of Indo-Fijian political leadership were well founded.

The SVT party, which lost the election, won only eight seats even though they obtained 38 per cent of the votes. One small indigenous party which won 9 per cent of the votes was given two seats in Cabinet. Another indigenous party which won 19 per cent of the vote was given a Deputy Prime Minister post plus three other Cabinet positions. A provincial-based indigenous party was given two Cabinet seats. The SVT party, which had won 38 per cent of the votes, had given certain conditions when it was invited to join the government. Understandably the Prime Minister, the Hon. Mahendra P. Chaudhry rejected the response of the SVT.

If the Prime Minister were to lead the country successfully he would have allowed the dust to settle, temperatures to cool, and then come back 
for a dialogue with the party that represented 38 per cent of the electorate.

Over the last 12 months the indigenous people have watched, with dismay, concern and resentment, Mr Chaudhry's blatant attempt to weaken, or if possible destroy important indigenous institutions, namely the Native Land Trust Board (NLTB) and the Great Council of Chiefs (GCC).

of course central to indigenous concern is their land. The indigenous people of Fiji own some 86 per cent of the land. But the ownership is not by individuals but by clans (Mataqali). In fact every indigenous generation has the right of usage of the land for which they have. It is their obligation to ensure the land, which the clan owns, is protected and passed on to the next generation.

It is interesting to note though that some of the best land has been completely alienated to private ownership, or has been used by IndoFijian cane farmers for the last 100-120 years. The lease fees for these lands, under cane farming, to put it charitably, are miserable. In the last 25 years, for instance, Fiji has been allowed to sell 160,000 tonnes of sugar to the European Union, at a rate that is three to four times the world price. Not a cent of this windfall has been given to the indigenous landowners, apart from their uneconomic lease fee. Moreover, it should be noted that over the years cane farmers owe a substantial amount of arrears to the NLTB.

The Agriculture and Landlord Tenancy Act (ALTA) which originally came as the Agriculture and Landlord Tenants Ordinance (ALTO) is now coming to an end. Under the Act, farmers were given 30 years to lease the land. Every farmer that entered a leasing arrangement, under the Act, knew that he had 30 years to farm the land, after which the lease expires. When the lease expires, unless the landowners wish to renew the lease, the tenants have to move out. Since 1997 or thereabouts, a number of farms under the ALTA arrangement have had their leases expire, and tenants are expected to go elsewhere if the indigenous landowners decide not to renew the lease. 
Since Mr Chaudhry came to power he has attempted to coerce the NLTB to continue granting leases to tenants under ALTA. This goes right against the face of a clearly stated policy of the Great Council of Chiefs and the NLTB that any renewal of leases will come under the Native Land Trust Act. As far as indigenous landowners are concerned, ALTA must and should be repealed. As far as the indigenous landowners are concerned ALTA is dead. Yet Mr Chaudhry has continued to fight the indigenous landowners on this issue. He seems unable to accept that the indigenous landowners have the right to decide the terms and conditions on which their land can be leased.

The Fiji Labour Party, since 1987, has advocated the establishment of a Land Use Commission. The late Dr Timoci Bavadra, who subsequently became Prime Minister when the Fiji Labour Party won the election in 1987, first presented the proposal to the Great Council of Chiefs. Since the government came to power in 1999 one of the most important elements in its policy platform is the establishment of a Land Use Commission.

Again the NLTB representing the indigenous landowners rejected this proposal. What is worse is that the Government, i.e. PM Chaudhry with his usual arrogance, which has become the trademark of his style of political leadership, is dismissive of the stand taken by the NLTB and his insistence that Land Use Commission be established in spite of the indigenous landowners opposition.

In fact, in an attempt to hoodwink and subvert traditional indigenous leadership, a representative group of indigenous chiefs was sent by PM Chaudhry to observe traditional land ownership in Sarawak, Malaysia.

The troubling aspect of the Chaudhry-led Government is its ongoing attempt to divide the indigenous people of Fiji. He has certainly mastered the tactics of divide and rule. For some time the previous government (SVT) had to put in place policy initiatives to assist the indigenous community to 'catch up', particularly in the field of education, and commerce, where indigenous participation is non-existent. Indeed, when one reflects on the debate that led to the passage of the 1997 Constitution, the Indo-Fijian political parties conceded absolutely nothing particularly in the field of commercial participation where their community holds all the cards. 
Even before the People's Coalition Party came to power, Mr Chaudhry was leading opposition spokesperson, who was always critical of affirmative action in favour of the indigenous community. And Mr Chaudhry, when he came to power saw that this affirmative action, in favour of the indigenous community, was removed. In its place, the social justice provisions of the 1997 Constitution were implemented with unbelievable speed and lack of consideration and consultation with the indigenous community. And now every community in Fiji will be put on an equal basis in spite of the fact that the Indo-Fijian community controls the economy.

The events that took place on 19 May, 2000 represent the culmination of 12 months of frustration, anger, disappointment and outrage in the manner in which the Chaudhry government dealt with matters of importance to the indigenous community. What is worse is that the nine indigenous Ministers in the Cabinet, two of whom are Deputy PM appear to be completely 'under the thumb' of the PM. They are, to put it elegantly, impotent almost to the point of being eunuchs in their ability and failure to safeguard what was perceived by the indigenous community as important to them. In fairness to the indigenous Cabinet Ministers the above judgement may appear to be unduly harsh. It would seem that none of the indigenous Ministers was ever able to articulate, either privately or publicly, what was important to the indigenous electorate, which they purport to represent and which elected them to Parliament.

It is useful to view the current crisis in Fiji in the context of numbers. The indigenous people of Fiji represent some 51 per cent of the Fiji population of approximately 790,000. From a global perspective, the indigenous population of Fiji does not merely have to deal with the 300,000 Indo-Fijians who are now citizens of the country. Against this number the indigenous community of Fiji have to take cognisance of the one billion people of India itself, and a substantial number of people of Indian origin in other parts of the world, notable Mauritius, Trinidad, Guyana and parts of East Africa. As well as this group, there are those who man some of the most important international institutions, such as the World Bank, the IMF and the United Nations system for development. 
As an indigeous people, we are part of the world's indigenous communities whose interests and precarious (some of whch borders on extinction) were singled out for special attention by the international community through declaration, the Decade of Indigenous People. Indeed, the indigenous people of Fiji are under threat and this dangerous threat is being undertaken by a government that was constitutionally elected and uses the provisions of the Constitution that would put in place laws that would bring greater disadvantage to the indigenous comunity of Fiji.

This letter is an attempt to provide your Excellency with a background of why the events of 19 May, 2000 had taken place. There is no going back. If the indigenous community do not assert their rights now and with regency, to govern their own country, they will in next to no time become history. The indigenous people of Fiji are not alone in this precarious position. Even the indigenous communities in our largest South Pacific states often find the going difficult.

The President of Fiji's dismissal of the genuine concerns of the indigenous community compounds the impasse of the last two days. The President appears reluctant to address these real and growing concerns.

The events of 19 May, 2000 could have been avoided if Mr Chaudhry had the ability and political courage to listen to the growing unrest of the indigenous people and step down. The country would have avoided all trouble if in his place a leader was appointed who would at least listen and dialogue with the indigenous people with urgency, from the start of his administration. In fact, from all his recent public statements, PM Chaudhry dismissed the marches as being the work of agitators and those who could not accept that they had lost the election. The present crisis lies squarely at the door of Mr Chaudhry, whose arrogance and refusal to listen to other viewpoints, contrary to his, are hallmarks of his style of governance. This of course is nothing new to those who knew him in his days in the Opposition. Chaudhry banked very much on the fact that he had an absolute majority in Parliament, and that sufficient mandate to run 'rough shod' over the concerns of the indigenous community.

Added to this, the grievance of the indigenous community was that the President ignored the grounds of dissatisfaction of the indigenous 
community as expressed throughout the media over the last 12 months. This then led to two public demonstrations which were then subsequently followed by a third demonstration that culminated in the entry of representatives of the indigenous people into Parliament.

There is no denying that the events of 19 May 2000 represent an assault of democracy and constitutionality. The events represented 'the last straw' to many members of the indigenous community. It was not meant to be vengeance nor violent. Those who did what they did on 19 May 2000 did so because it was the only way available to them to bring to the attention of the powers that be that the concerns of the indigenous community are real and need to be addressed with urgency.

It is well within the moral high position of the President of Fiji to persuade the PM and his government to voluntarily resign. It would give the opportunity, under the State of Emergency, to appoint an Interim Government drawn from all major political parties. The task of such a government is first and foremost to address the grievances of the indigenous community in the light of the 1997 Constitution. Unfortunately, to date, the President appears reluctant to adopt this path that could lead to immediate stability, reconciliation among the major communities, economic growth and development. This would be well within the legal powers of the President of Fiji since he has declared a State of Emergency. such prudent and statesman-like action would have found acceptance and approval by the international community. 